아르곤 플라스마 응고소작술로 치료한 담관내 유두상 점액 종양

부산대학교 의학전문대학원, 부산대학교병원 의생명연구원 ${ }^{1}$ 내과학교실, ${ }^{2}$ 병리학교실

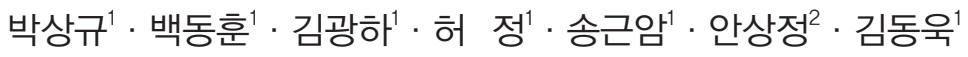

\title{
Intraductal Papillary Mucinous Neoplasms of the Bile Duct Treated with Argon Plasma Coagulation
}

\author{
Sang Gyu Park', Dong Hoon Baek', Gwang Ha Kim', Jeong Heo', Geun Am Song', Sang Jeong Ahn², Dong Uk Kim \\ Departments of 'Internal Medicine and 'Pathology, Pusan National University Hospital, Biomedical Research Institute, Pusan National Univer- \\ sity School of Medicine, Busan, Korea
}

Intraductal papillary mucinous neoplasm of the bile duct (IPMN-B) is frequently found and has recently been recognized as a precancerous lesion leading to invasive carcinoma characterized by papillary growth of the ductal epithelium with rich mucin production and cystic dilatation of the hepatic duct. Surgical resection is the treatment of choice to avoid malignant transformation. Despite a growing number of studies on IPMN-B, there are few reports of its treatment aside from surgery. A 75-year-old woman was incidentally diagnosed as IPMN-B. Considering the patient's age, comorbidity, and preference, we recommended an argon plasma coagulation (APC) as local ablation therapy rather than surgical resection. There was no evidence of remnant tumor on percutaneous transhepatic cholangioscopy 4 weeks after the ablation of tumor mass by using APC. We report a rare case of IPMN-B successfully treated with APC.

Korean J Pancreas Biliary Tract 2017;22(1):39-45

Keywords: Argon plasma coagulation, Bile duct neoplasms, Mucin, Treatment
Received Jun. 13, 2016
Revised Aug. 23, 2016
Accepted Aug. 25, 2016

Corresponding author : Dong Uk Kim

Department of Internal Medicine, Pusan National University Hospital, Biomedical Research Institute, Pusan National University School of Medicine, 179 Gudeok-ro, Seo-gu, Busan 49241, Korea Tel. +82-51-240-7869 Fax. +82-51-244-8180 E-mail; amlm3@hanmail.net

This is an Open Access article distributed under the terms of the Creative Commons Attribution Non-Commercial License (http:// creativecommons.org/licenses/by-nc/3.0/) which permits unrestricted non-commercial use, distribution, and reproduction in any medium, provided the original work is properly cited.

Copyright $\odot 2017$ by The Korean Journal of Pancreas and Biliary Tract

\section{INTRODUCTION}

Intraductal papillary mucinous neoplasm of the bile duct (IPMN-B) is a rare but increasingly diagnosed clinical entity. The lesion is a bile duct tumor with a macroscopic papillary appearance and visible mucin secretion. It is considered a biliary variant of intraductal papillary mucinous neoplasm of the pancreas (IPMN-P) which is composed of numerous papil- lary fronds with fine fibrovascular cores. ${ }^{1}$

This clinical entity is a precursor of invasive carcinoma, and $40-80 \%$ of resected IPMN-Bs contain invasive components. ${ }^{2}$ Therefore, most cases are treated surgically. However, conservative therapy was considered for inoperable patients with complication, old age and performance status. Recently, local ablation therapy has been proposed as an alternative palliative or curative treatment for tumors with intermediate malignant characteris- 
tics, but its role in the management of IPMN-B has not been completely investigated. We report a rare case of an IPMN-B successfully treated with argon plasma coagulation (APC).

\section{CASE}

The patient is a 75-year old woman who was admitted due to epigastric pain. She had undergone percutaneous transhepatic cholangioscopy (PTCS) with electrohydraulic lithotripsy 8 years before to remove a common bile duct stone and intrahepatic duct (IHD) stones. During this admission, the results of biochemical tests were unremarkable. Contrast-enhanced abdominal and pelvic computed tomography (CT) revealed IHD dilatation accompanied by multiple stones of right IHD and mural nodules of left IHD. The mural nodules exhibited isodense and hyperdense attenuation during the late arterial phase and isodense attenuation during the portal-venous and delayed phases (Fig. 1). Magnetic resonance image (MRI) showed marked dilatation of the left intrahepatic duct and bile duct in the T2-weighted image (WI). There were linear filling defect lesions of bile duct at 60 minutes delay in the T1-WI. The lesions

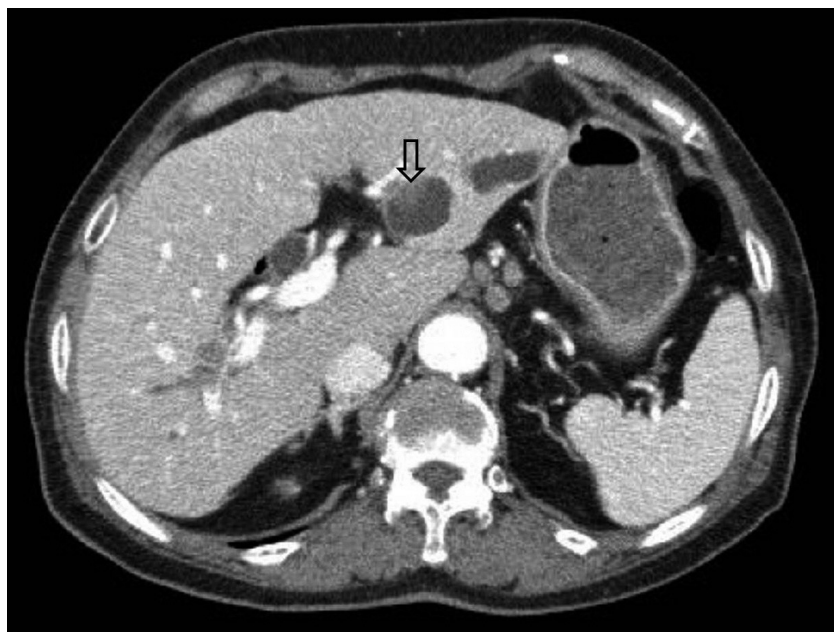

Fig. 1. Contrast-enhanced abdominal and pelvic computed tomography scan reveals intrahepatic duct dilatation due to intrahepatic ductal mural nodule (intraductal papillary mucinous neoplasm of the bile duct) (black arrow).
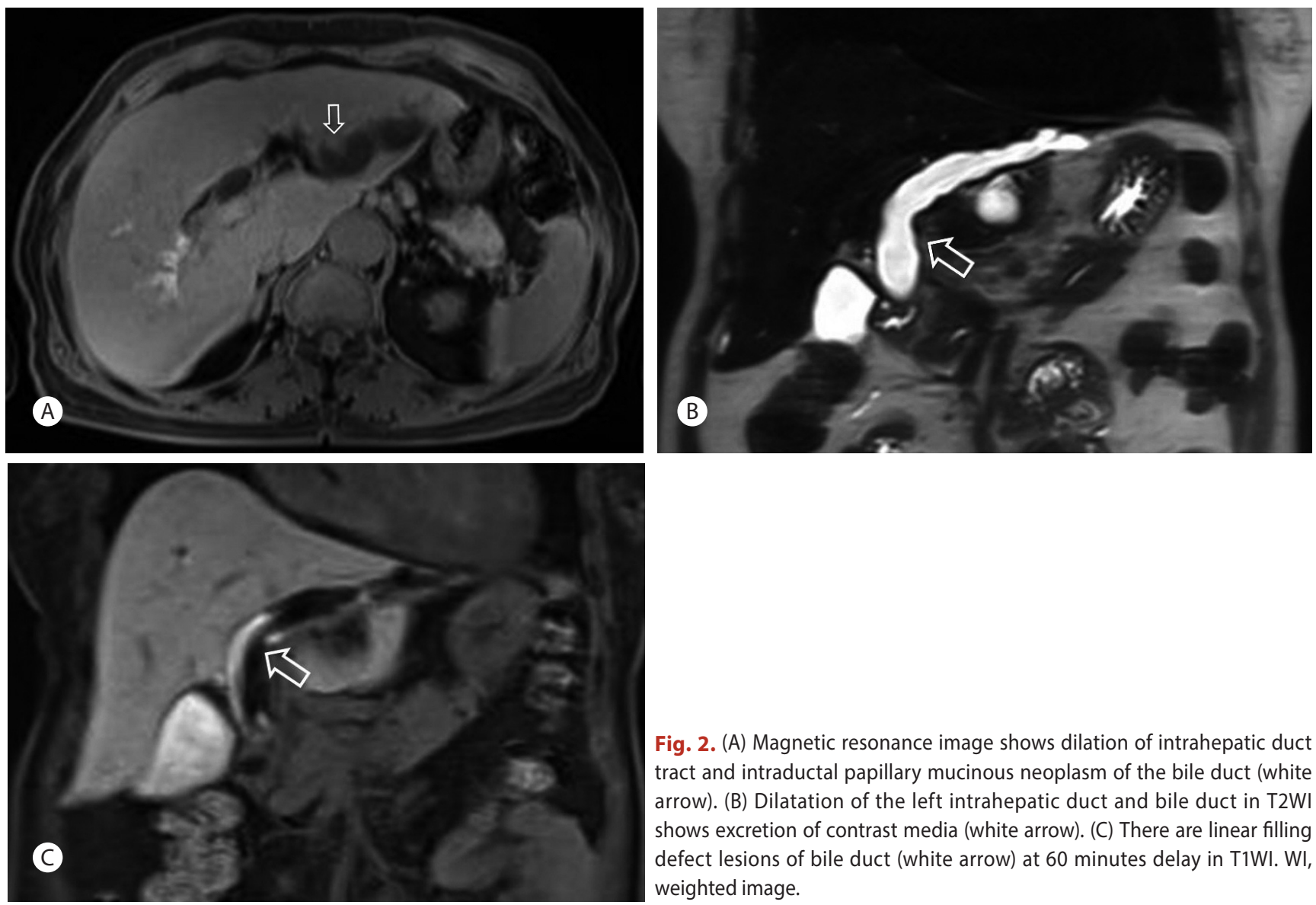

Fig. 2. (A) Magnetic resonance image shows dilation of intrahepatic duct tract and intraductal papillary mucinous neoplasm of the bile duct (white arrow). (B) Dilatation of the left intrahepatic duct and bile duct in T2WI shows excretion of contrast media (white arrow). (C) There are linear filling defect lesions of bile duct (white arrow) at 60 minutes delay in T1WI. WI, weighted image. 
were mucin secretions of mural nodules. These findings suggested a diagnosis of a left intraheptic IPMN-B (Fig. 2).

Because of given her old age and Eastern Cooperative Oncology Group score 3, we recommended conservative management instead of surgical treatment. She chose APC ablation therapy under the information of various treatment options. Percutaneous transhepatic biliary drainage was performed, and the transhepatic tract was sequentially dilated by introducing transhepatic plastic dilators of increasing diameter (up to $18 \mathrm{Fr}$ ). IHD stones were then removed by PTCS (CYF-VA2, Olympus Optical Co., Tokyo, Japan), and the intrahepatic papillary lesion was simultaneously biopsied. The histopathological diagnosis of low-grade IPMN was thereby confirmed (Fig. 3).

A lot of mucin and intraductal papillary projection were shown in main left IHD. Two sessions of APC ablation thera- py were subsequently performed to reduce mucin production (Fig. 4). Subsequently APC ablation was repeatedly per-

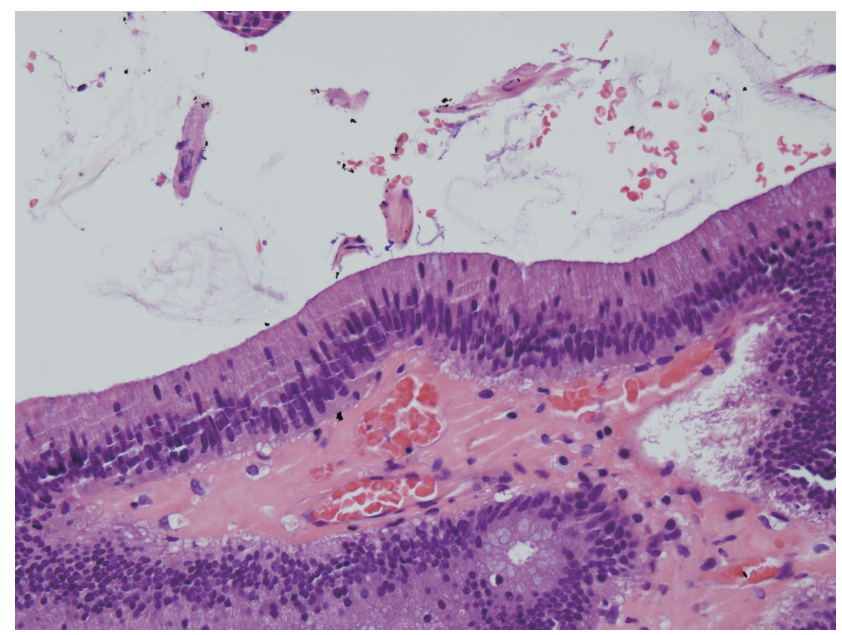

Fig. 3. Left intrahepatic bile duct biopsy shows papillae with fibrovascular core was lined with dysplastic biliary epithelium of low grade $(H \& E, \times 400)$.
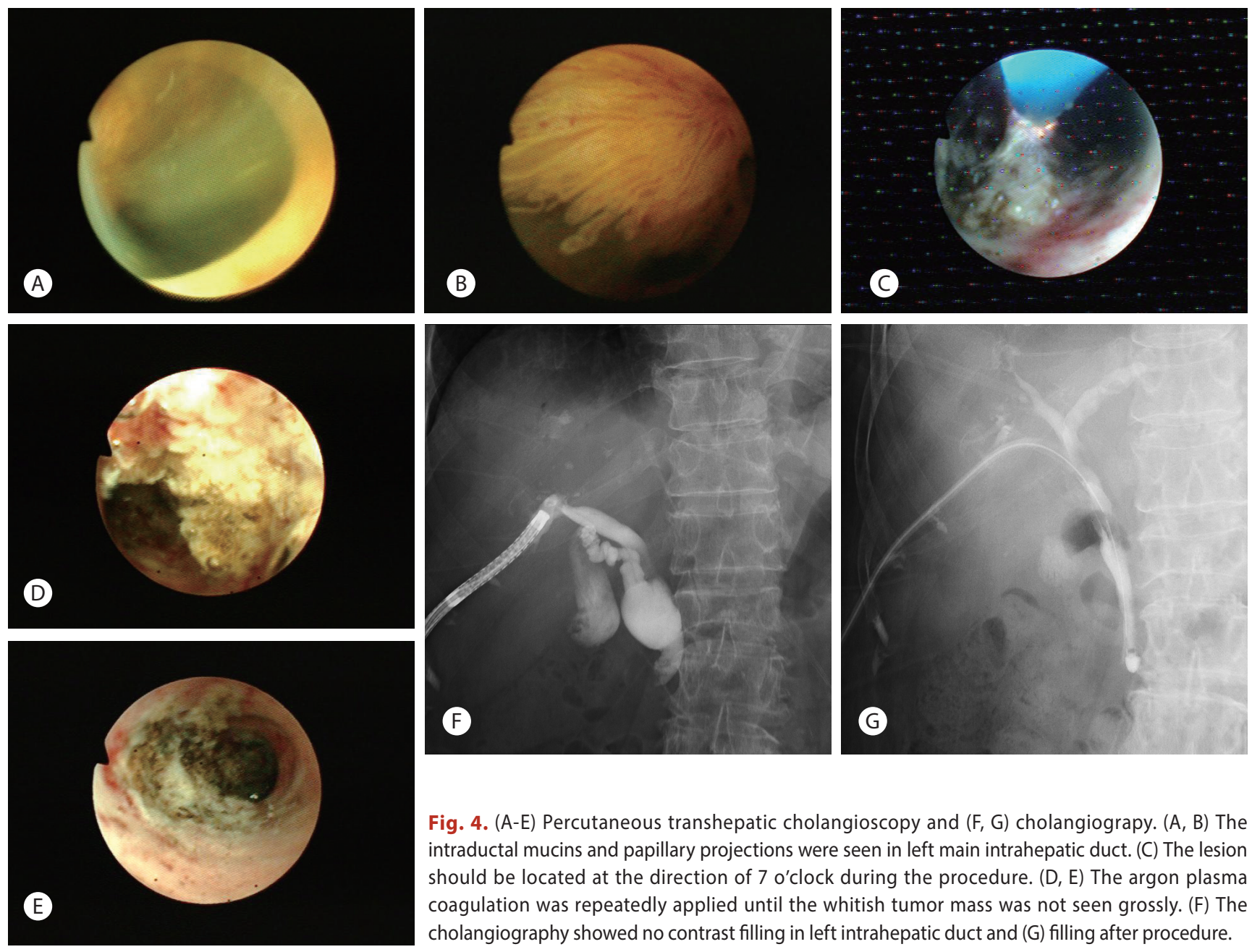

Fig. 4. (A-E) Percutaneous transhepatic cholangioscopy and (F, G) cholangiograpy. (A, B) The intraductal mucins and papillary projections were seen in left main intrahepatic duct. (C) The lesion should be located at the direction of 7 o'clock during the procedure. (D, E) The argon plasma coagulation was repeatedly applied until the whitish tumor mass was not seen grossly. (F) The cholangiography showed no contrast filling in left intrahepatic duct and (G) filling after procedure. 

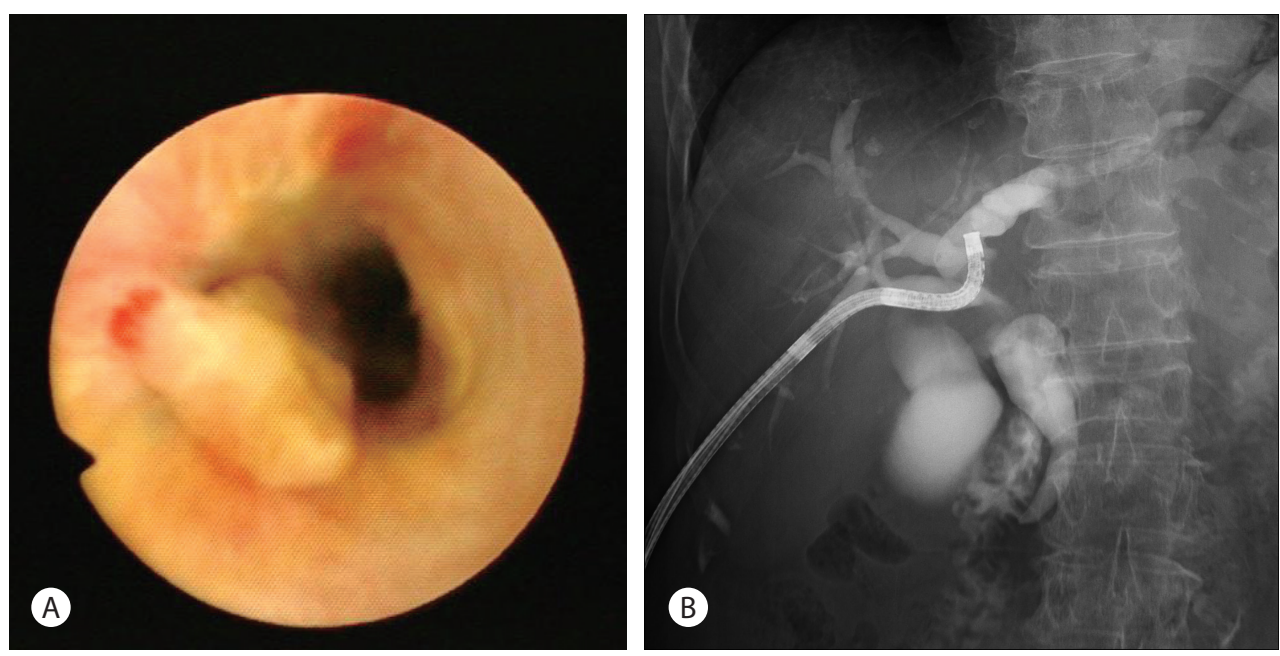

Fig. 5. (A) Follow-up percutaneous transhepatic cholangioscopy shows a scar change without definite lesion of papillary projection, 1 month after argon plasma coagulation, (B) Follow-up percutaneous transhepatic cholangiography reveals focal stricture in left main intrahepatic duct suspected as benign lesion, 1 month after argon plasma coagulation.

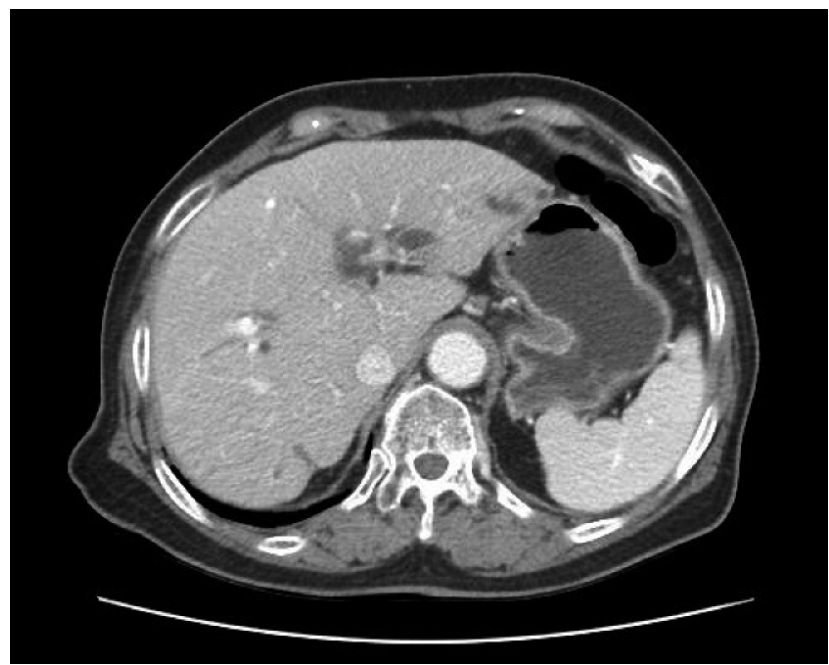

Fig. 6. Follow-up contrast-enhanced abdominal and pelvic computed tomography scan shows decreased left intrahepatic duct dilatation and an absence of multifocal mural.

formed until the white tumor tissue was not visible with the naked eye. However the patient could not tolerate the procedure for a prolonged duration owing to her age, the procedure was conducted over 2 sessions. We used a VIO 300D system (ERBE, Marietta, GA, USA) in forced APC mode at a gas flow/power setting of $1.0 \mathrm{~L} / \mathrm{min}$ and 30 watts in conjunction with a Straight Fire probe (FiAPC probe 2200A, Ø2.3 $\mathrm{mm}$, flexible, length $2.2 \mathrm{~m}$ ) (ERBE, Marietta, GA, USA).

One month later, the patient underwent follow-up PTCS with a forceps biopsy that was negative for malignancy (Fig. 5). Four months later, a follow-up contrast-enhanced abdominal and pelvic CT showed no definite lesion of the mural nodule and markedly decreased both IHD dilatation com- pared with previous image findings (Fig. 6). But, left IHD presented a slight dilatation due to suspected benign stricture without definite mass lesion. Currently, the patient is asymptomatic and in good clinical condition. The disease is stable, and she is regularly observed on an outpatient basis.

\section{DISCUSSION}

IPMN-B is characterized by predominantly intraductal papillary growth and may be located anywhere along the biliary tree. It can display any degree of pathological transformation from low-grade dysplasia to invasive carcinoma. ${ }^{1}$ In the past, such growths were identified by various names such as biliary papillomatosis, mucin-producing cholangiocarcinoma, mucin-hypersecreting bile duct tumor, and biliary intraductal papillary mucinous neoplasm. ${ }^{2}$ The term IPMN-B was adopted in the 2010 World Health Organization classification as a distinct clinical and pathologic entity. ${ }^{3}$

IPMN-B is mainly found in eastern Asian locations such as Taiwan, Japan, and Korea, where hepatolithiasis and clonorchiasis are endemic. Papillary cholangiocarcinoma accounts for approximately $4-38 \%$ of all bile duct adenocarcinomas. ${ }^{4}$

The most common presenting symptom is abdominal pain, probably due to biliary stones, cholangitis, or high pressure in the biliary tract causing mucin hypersecretion. ${ }^{5,6}$ Wang et al. ${ }^{2}$ reported that the process of inflammatory stimulation due to biliary stones may play a role in the development of IPMN-B.

Radiologic (e.g., ultrasonography, CT, MRI) findings of 
IPMN-B include bile duct dilatation and intraductal masses. Direct cholangiography (e.g., endoscopic retrograde cholangiography) is useful for the detection of mucobilia, which is seen in nearly one-third of patients with IPMN-B, evidenced by diffuse dilatation of the bile duct with an amorphous filling defect. ${ }^{6}$ Cholangioscopy, including PTCS and peroral cholangioscopy, can be used to approach the bile duct directly, confirm the histology, and assess the extent of the tumor, including superficial spreading along the biliary epithelium, which provides information that can be used to choose the appropriate treatment. ${ }^{7,8}$

In this patient, contrast-enhanced abdominal and pelvic CT was performed because the patient was experiencing epigastric pain, and IHD dilatation accompanied by IHD stones and possible cholangiocarcinoma were revealed. MRI, performed in preparation for IHD stone removal, identified a multifocal mural nodule suspicious for IPMN-B. This diagnosis was confirmed by PTCS biopsy.

IPMN-B may behave more aggressively than IPMN-P. Recently, Sclabas et al. ${ }^{9}$ suggested that based on mucin glycoprotein (MUC) expression patterns (high frequency of MUC1 expression and/or absence of MUC2 expression), IPMN-B displays similarities to main duct IPMN-P, which is more aggressive than branch duct IPMN-P. ${ }^{10}$

The risk factors for a potentially malignant IPMN-P include main duct IPMN-P, male sex, advanced age, tumor size $>2$ $\mathrm{cm}$, mural nodes in the cyst, symptoms, distension of the pancreatic duct or bile duct, enlarged lymph nodes, positive cytology, and carcinoembryonic antigen $>200 \mathrm{ng} / \mathrm{mL}$ in the cyst's contents. ${ }^{11}$ Because of the significant risk of malignancy, surgical resection is the treatment of choice for IPMN-P.

IPMN-B in common with IPMN-P should be removed sur-

Table 1. Previously reported palliative therapies for intraductal papillary mucinous neoplasm of the bile duct

\begin{tabular}{|c|c|c|c|c|}
\hline Treatment & Procedure & Mechanism & Benefits & Limitations \\
\hline $\begin{array}{l}\text { Radiofrequency } \\
\text { ablation (RFA) }\end{array}$ & $\begin{array}{l}\text { Propagation of heat energy using } \\
\text { electrode and RF generator } \\
\text { - Electrode : a unique design featuring } \\
7 \mathrm{~mm} \text { total length with two } 0.8 \mathrm{~mm} \\
\text { diameter holes located } 5 \mathrm{~mm} \text { from the } \\
\text { tip } \\
\text { - RF generator : modulation by an } \\
\text { automatic power control unit }\end{array}$ & $\begin{array}{l}\text { Sustained thermal } \\
\text { damage to the } \\
\text { epithelium, resulting } \\
\text { in destruction of the } \\
\text { inner epithelial lining } \\
\text { of the cyst }\end{array}$ & $\begin{array}{l}\text { Effective for small } \\
\text { to medium-sized } \\
\text { tumors with fewer } \\
\text { complications }\end{array}$ & $\begin{array}{l}\text { For larger lesion, } \\
\text { an increased risk } \\
\text { of residual and } \\
\text { recurrence }\end{array}$ \\
\hline Laser ablation $^{13}$ & $\begin{array}{l}\text { Holmium laser fulguration ( } 8 \mathrm{~W} \text { ) to the } \\
\text { lesion }\end{array}$ & $\begin{array}{l}\text { Destruction and removal } \\
\text { of tumor using a high- } \\
\text { frequency electric } \\
\text { current applied with a } \\
\text { needle-like electrode }\end{array}$ & $\begin{array}{l}\text { Minimally invasive, quick } \\
\text { and easy treatment } \\
\text { option }\end{array}$ & $\begin{array}{l}\text { Relatively high cost of } \\
\text { the laser equipment } \\
\text { Lack of tissue for } \\
\text { histology } \\
\text { Risk of recurrence }\end{array}$ \\
\hline $\begin{array}{l}\text { Photodynamic } \\
\text { therapy (PDT) }\end{array}$ & $\begin{array}{l}\text { Delivery of light to the target area using } \\
\text { endoscopes and fiberoptic catheters } \\
\text { after administering photosensitizers } \\
\text { intravenously } \\
\text { - Penetration depth of } 5-6 \mathrm{~mm} \text {, } \\
\text { depending on the physical attributes of } \\
\text { the surrounding tissue (particle scatter, } \\
\text { light absorption, etc.) }\end{array}$ & $\begin{array}{l}\text { Producing localized } \\
\text { tissue necrosis } \\
\text { with light (most } \\
\text { conveniently from } \\
\text { a laser) after prior } \\
\text { administration of a } \\
\text { photosensitizers in the } \\
\text { presence of oxygen }\end{array}$ & $\begin{array}{l}\text { Simpler and a shorter } \\
\text { recovery time than } \\
\text { any form of treatment } \\
\text { Relatively low incidence } \\
\text { of serious treatment } \\
\text { related complications }\end{array}$ & $\begin{array}{l}\text { Causing some necrosis in } \\
\text { adjacent normal tissue } \\
\text { where normal and } \\
\text { neoplastic tissue meet } \\
\text { Cutaneous } \\
\text { photosensitivity } \\
\text { Relatively high cost } \\
\text { Risk of recurrence }\end{array}$ \\
\hline $\begin{array}{l}\text { Argon plasma } \\
\text { coagulation }(A P C)^{15}\end{array}$ & $\begin{array}{l}\text { Using argon gas to deliver plasma of } \\
\text { evenly distributed thermal energy to a } \\
\text { field of tissue adjacent to the probe } \\
\text { - Penetration depth of } 2-3 \mathrm{~mm}\end{array}$ & $\begin{array}{l}\text { Coagulating tissue } \\
\text { which employs a high } \\
\text { frequency electric } \\
\text { current and ionised } \\
\text { argon gas }\end{array}$ & $\begin{array}{l}\text { Ability to treat large } \\
\text { surface and superficial } \\
\text { depth quickly } \\
\text { Ease of application, } \\
\text { speedy treatment of } \\
\text { multiple lesions } \\
\text { Relatively lower cost }\end{array}$ & Risk of recurrence \\
\hline
\end{tabular}


gically because of potential malignancy. When resection cannot be performed, palliative treatments are recommended. Several options are available for the treatment of inoperable patients including radiofrequency ablation (RFA), laser ablation, photodynamic therapy (PDT), and APC (Table 1). RFA is an efficient and safe treatment for the palliation of unresectable malignant biliary obstructions. ${ }^{12}$ However, this method is effective for only small to medium-sized tumors because it uses heat to achieve contact coagulative necrosis of surrounding tissue. Laser ablation may also have value for palliation but the cost of equipment is relatively high. ${ }^{13}$ PDT showed early promise but has demonstrated a high complication rate including cholangitis due to necrosis in adjacent normal tissue and photosensitivity. ${ }^{14}$ APC uses argon gas to deliver plasma of evenly distributed thermal energy to a field of tissue adjacent to the probe. ${ }^{15}$ These treatments help improve quality of life by reducing tumor size, reducing jaundice, or reducing symptom. However, when compared to surgical treatment, these modalities have a higher rate of tumor recurrence because of limitations such as low penetration depth and a small extent. To date, no clinical trials on these treatments have been published except for some case reports. ${ }^{14}$

To date, most cases of IPMN-B are treated surgically. In our patient's case, surgery was not a viable option. APC ablation therapy is known to treat large surface areas relatively quickly. In this case, it was recommended to reduce mucin production and thereby decrease the size of the dilated duct. Brauer et al. ${ }^{15}$ reported a case of IPMN-B treated with APC ablation therapy that was not successful; the patient died of refractory hepatic encephalopathy one month later. In this case, the patient is asymptomatic and in good clinical conditions eight months after diagnosis.

Our findings suggest that APC could be used as an alternative treatment for some patients with inoperable IPMN-B.

\section{요 약}

담관내 유두상 점액 종양은 담관내에서 흔히 발견되며, 최 근에는 전암성 병변으로 인식되어 왔다. 담관내 상피세포의 유듀상 성장과 점액생성 및 그로 인한 간내담관의 확장을 특
징으로 한다. 수술적 절제가 악성 변화를 막기 위한 최선의 방법이다. 담관내 유두상 점액 종양에 대한 연구가 증가하고 있지만 수술이외의 치료에 대한 보고는 많지 않다. 우리는 75세 여자 환자가 우연히 담관내 유두상 점액 종양으로 진단 받고 아르곤 플라즈마 응고소작술로 성공적 치료를 받은 경 우를 보고한다. 환자의 나이와 동반질환 등을 고려하여 수술 적 절제보다는 아르곤 플라즈마 응고소작술을 시행하였고, 치료 4주 후 시행한 경피 경간 담도내시경에서 잔여종양의 증거는 없었다.

국문 색인: 아르곤 플라스마 응고소작술, 담관내 유두상 점 액 종양, 치료

\section{REFERENCES}

1. D'souza MA, Isaksson B, Löhr M, et al. The clinicopathological spectrum and management of intraductal papillary mucinous neoplasm of the bile duct (IPMN-B). Scand I Gastroenterol 2013;48:473-479.

2. Wang X, Cai YQ, Chen YH, Liu XB. Biliary tract intraductal papillary mucinous neoplasm: Report of 19 cases. World J Gastroenterol 2015;21:4261-4267.

3. Nakanuma Y, Curado MP, Franceschi S, et al. Intrahepatic cholangiocarcinoma. In: Bosman FT, Carneiro F, Hruban R, Theise N, eds. WHO classification of tumours of the digestive system, 4th ed. p217, Lyon, IARC, 2010.

4. Terada T. Non-invasive intraductal papillary neoplasms of the common bile duct: a clinicopathologic study of six cases. Int J Clin Exp Pathol 2012;5:690-697.

5. Rocha FG, Lee $H$, Katabi $N$, et al. Intraductal papillary neoplasm of the bile duct: a biliary equivalent to intraductal papillary mucinous neoplasm of the pancreas? Hepatology 2012;56:1352-1360.

6. Wan XS, Xu YY, Qian JY, et al. Intraductal papillary neoplasm of the bile duct. World J Gastroenterol 2013;19:8595-8604.

7. Tsuyuguchi $T$, Sakai $Y$, Sugiyama $H$, et al. Endoscopic diagnosis of intraductal papillary mucinous neoplasm of the bile duct. J Hepatobiliary Pancreat Sci 2010;17:230-235.

8. Tsou YK, Liu NJ, Wu RC, et al. Endoscopic retrograde cholangiography in the diagnosis and treatment of mucobilia. Scand J Gastroenterol 2008;43:1137-1144.

9. Sclabas GM, Barton JG, Smyrk TC, et al. Frequency of subtypes of biliary intraductal papillary mucinous neoplasm and their MUC1, MUC2, and DPC4 expression patterns differ from pancreatic intraductal papillary mucinous neoplasm. J Am Coll Surg 2012;214:27-32.

10. Minagawa N, Sato N, Mori Y, Tamura T, Higure A, Yamaguchi K. A comparison between intraductal papillary neoplasms of the biliary 
tract (BTIPMNs) and intraductal papillary mucinous neoplasms of the pancreas (P-IPMNs) reveals distinct clinical manifestations and outcomes. Eur J Surg Oncol 2013;39:554-558.

11. Grützmann R, Post $S$, Saeger HD, Niedergethmann M. Intraductal papillary mucinous neoplasia (IPMN) of the pancreas: its diagnosis, treatment, and prognosis. Dtsch Arztebl Int 2011;108:788-794.

12. Park JS, Seo DW, Song TJ, et al. Endoscopic ultrasound-guided ablation of branch-duct intraductal papillary mucinous neoplasms: feasibility and safety tests using porcine gallbladders. Dig Endosc 2016;28:599-606.

13. Baughman SM, Bishoff JT, Zimmerman MK, Carter MR, Kerby JD,
Watkins KT. Case report: serial percutaneous cholangioscopy with laser ablation for the management of locally recurrent biliary intraductal papillary mucinous tumor. J Gastrointest Surg 2005;9:215-218.

14. Topazian M, Zhong N, Baron TH, Vege SS, Wang KK. Photodynamic therapy of intraductal papillary mucinous neoplasm. Endoscopy 2012;44:213-215.

15. Brauer BC, Fukami N, Chen YK. Direct cholangioscopy with narrowband imaging, chromoendoscopy, and argon plasma coagulation of intraductal papillary mucinous neoplasm of the bile duct (with videos). Gastrointest Endosc 2008;67:574-576. 